\title{
HERA AND JUNO IN THE ARGONAUTICA
}

\begin{abstract}
Summary: The article deals with the role of the Greek goddess Hera and her Roman counterpart, Iuno, in the poetic treatments of the myth of Argonauts. The focus is put especially on Iuno's character development in Valerius Flaccus' adaptation of the myth. Iuno's character in this work has already been discussed by Werner Schubert in his fundamental study (1991), in which he pointed out the remarkable approximation of Iuno fabulosa and Iuno civilis. Referring to this study, the article emphasizes rather the literary development of Iuno's character. It is shown that Valerius Flaccus portrays the highest goddess not only as a peculiar helper (socia), as suggested by Schubert, but also as a permanent participant in an intertextual dialogue with the epic poems of Homer and Apollonius Rhodius. Valerius Flaccus' aim here is to invert his literary predecessors' accounts in a subtle and witted way (as Debra Hershkowitz has already presented).
\end{abstract}

Key words: Iuno, Hera, Valerius Flaccus, Apollonius Rhodius, intertextuality

In Roman epic literature, the character of Juno is commonly associated with the emotion of relentless anger. Although often abated, as is the case at the end of Aeneid (XII 808ff.), wrath never really abandons her character, finding its expression in her persecution of many epic heroes. Even the Romans are left unprotected against Juno's anger, and although no need for fear is stated at the conclusion of Virgil's poem - under the condition that the Romans do not choose to bear a name referring to their Trojan origin (Aen. XII 818-828) - they will face her anger, as shown in the epics about the Punic wars. ${ }^{1}$ Roman poetry thus primarily presents us with a portrayal of an unforgiving Homer's goddess. Some scholars argue convincingly, however, that there are yet other sides of the queen of the Gods. ${ }^{2}$ One of them as illustrated in the epic poem

\footnotetext{
${ }^{1}$ See BuChHeit 1963, 54; FEeney 1984, 174.

${ }^{2}$ See e. g. Johnston in this volume.
} 
Argonautica, authored by Valerius Flaccus has been presented by Werner Schubert (1991) in his inspiring study.

Schubert pursues the argument that Juno is - rather unusually - portrayed in the poem as socia (Val. Fl. I 73). ${ }^{3}$ This is evident at the moment when Jason decides on how to handle the order of King Pelias to retrieve the Golden Fleece from remote Colchis (Val. Fl. I 71-76). He is well aware of the danger associated with such an adventure. At first, he considers turning to his people for help in dethroning the tyrant king, avoiding directly facing a considerable danger. But eventually he decides to set off for the voyage and hopes instead for help from the goddess Juno and goddess Pallas Athena: an socia Junone et Pallade fretus (Val. Fl. I 73). With this important note, Schubert develops a convincing argument, claiming that in the character of the chief goddess Valerius Flaccus applied interpretatio Romana to theologia fabulosa in order to account for the Roman theologia civilis. ${ }^{4}$ The Argonauts of Valerius carry out an important task. Although their challenger seems to be the King of Iolcos, Pelias, the king of the Gods, Jupiter, explicitly states that the voyage follows his "historic" plan. Jupiter distances himself from the calm rule of his father Saturn (Val. Fl. I 500) and the voyage of the Argonauts opens a new era in the history of humankind. Juno becomes Jason's divine protectress and an enthusiastic supporter of the Argonauts, uniting thus with her husband and supporting his plans. ${ }^{5}$ And this harmony between the intents of the divine couple and especially Juno's "history-creating" activity are exactly the roles unheard of in relation to her character. The reader is obviously reminded of her previous rebelliousness against Jupiter (Val. Fl. II 82-86) and her famous indignation towards Jupiter's mistresses (for example, the chasing of Io: Val. Fl. IV 354ff.) and their children (mainly Hercules, who joins the voyage of the Argonauts; Juno's hatred of Hercules is obvious, e.g. in Val. Fl. I 110-117; III 510-520), but this is not to be viewed as a negative portrayal of the goddess, according to Schubert, but rather as a proof that even the gods are capable of internal growth, ${ }^{6}$ and possibly also a proof of Juno's lack of foresight - since in the end, she does not have Jupiter's awareness of the world's course of events. ${ }^{7}$ Schubert thus offers a most interesting and unusual - in mythological literature - perspective into Juno's personality. In this article, I would like to expand on this perspective and present yet another important feature that makes the analysis of the character of Valerius' queen of the Gods worth our attention.

Albeit on the side of her husband and supportive of his plans, Juno is clearly following her own interest, needless to say. She does not long for the end of human inactivity as Jupiter does, but rather for the Golden Fleece, which was promised to her and to Athena by Jason (Val. Fl. I 85). The Argonauts get engaged in a local conflict in Colchis in hope for a reward in the form of the fleece of the golden-hair ram promised to them by Aeëtes (Val. Fl. V 532ff., and mainly Book VI). Juno can see, however, that such a path

\footnotetext{
${ }^{3}$ SCHUBERT 1991, 125.

${ }^{4}$ SCHUBERT 1991, $127 \mathrm{ff}$.

${ }^{5}$ SCHUBERT 1991, $128 \mathrm{ff}$.

${ }^{6}$ SCHUBERT 1991, 130.

${ }^{7}$ SCHUBERT 1991, 132.
} 
will not lead to the dream trophy, and that King Aeëtes will become treacherous. The goddess is therefore considering an alternative way of helping the heroes to retrieve the fleece and to support them on the dangerous journey back (Val. Fl. VI 429ff.). The only solution she can envisage is to bring Princess Medea, a sorceress par excellence, who has no fear (Val. Fl. VI 439-454), on the side of the Argonauts. She has confidence in Medea's abilities and her passionate character, and decides to make Medea to fall in love with the chief of the Greek heroes. She therefore turns to Venus, goddess of love, for help.

At this moment, the well-known scene from Homer (Il. XIV 187-223) begins to unfold. In the Iliad (XIV 160ff.), Hera wishes to confuse the "mind of Zeus that

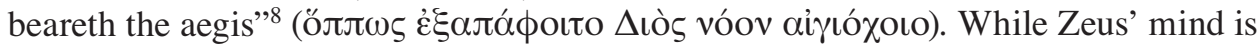
to be lulled to sleep to allow Poseidon to support the fight of the Greek army, Medea is to be stirred up into great actions. In the Iliad, Hera decides to enchant Zeus by means of her attractive appearance; she asks Aphrodite to lend her the charm of seductiveness, irresistible to both the Gods and mortals:

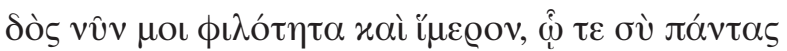

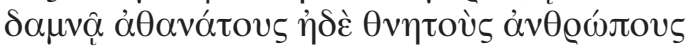

(Il. XIV 198-199)

Give me now love and desire, wherewith thou art wont to subdue all immortals and mortal men.

She justifies her plea with the excuse that her guardians, Tethys and Oceanus, are quarrelling; Hera wishes, she says, to return a favour to them for their earlier care (Il. XIV 200-210). Hera must choose the lie for strategic reasons, as Aphrodite sides with the opponents in the Trojan War (XIV 191-192), and her real intent - to seduce Zeus - is thus not to be revealed.

Valerius' goddess then visits Venus to ask the same favour (Val. Fl. VI, 455468): she also wishes to lend the winning allurement of a cunningly wrought beauty and Venus's adornments that have power both on earth and in heaven: ${ }^{9}$

\section{da, precor, artificis blanda adspiramina formae} ornatus que tuos terra caelo que potentes!

(Val. Fl. VI 465-466)

She says her reason is her marital disagreement with Jupiter, whom she says is avoiding sharing a bed with her since the time Heracles left Greece (Val. Fl. VI 460). Venus' charm is thus sought to seduce Zeus; in other words, the true intentions of Homer's Hera - to enchant the chief God and to have a sexual intercourse with him - become, in Valerius, Juno's excuse. At the same time, Juno seems to be aware of the similarity of situations in which the two goddesses have found themselves in poetry before. Since Hera's trickery was revealed in Homer's epic, the trustworthiness of Juno is now

\footnotetext{
${ }^{8}$ All translations of Homer by MURRAY 1924.

${ }^{9}$ All translations of Valerius Flaccus by MOZLEY $19722^{2}$.
} 
shaken, and she is aware of it. Possibly also for this reason, Valerius' Juno then introduces her plea by the following words:

'in manibus spes nostra tuis omnis que potestas

nunc.' ait 'hoc etiam magis adnue vera fatenti. ～(Val. Fl. VI 460-461)

In thy hands all my hope now lies, and all my power;

all the more then grant this boon, for it is truth I tell thee.

That is, this time, no plot but rather truth is involved, and therefore I am asking for a favour - this is Juno's message to the Roman goddess of love. As the voyage of the Argonauts precedes the Trojan War in mythic history, her present caution and swearing on truth are unlikely to come from her extraordinary memory, because of which she is associated with Moneta in Rome, ${ }^{10}$ but rather from Valerius' careful reading of the father of epic poetry.

Valerius' Juno does receive what she asks for from Venus: the marvelous belt which arouses irresistible desire. Proceeding to Medea, Juno takes on the appearance of Medea's sister Chalciope, changing thus also the main literary source of inspiration for her acts. Homer's Iliad is here replaced by Valerius' Hellenistic predecessor, Apollonius Rhodius. In his Argonautica, the true Chalciope, Medea's sister, appears, and, more importantly, the mother of three sons: Argus, Phrontis and Melas, whom she had borne to Phrixus, a hero who had travelled all the way to Colchis, riding the golden ram. The young men decide to return to their father's homeland in their adulthood; having been ship-wrecked on a desert island, they join the Argonauts on their way to Colchis. Jason welcomes on board his newly-found relatives, who later help him - as knowledgeable locals - with valuable assistance. One part of this assistance is in gaining support [for Jason] from their aunt, Medea, the mighty sorceress, with the aid of their mother, Chalciope.

Chalciope knows her father well, and anticipates danger for both Jason and his crew, to whom her sons now belong, and therefore is inclined to heed her sons' request, albeit somewhat fearful of asking Medea for the favour. In the meantime, Medea falls in love with Jason, having been shot by Eros' arrow of irresistible love. Eros acts upon the command of his mother Aphrodite, who in turn is led to command this by the goddess Hera during their private visit. She also wishes to support Jason in his quest for the golden fleece, and, together with Pallas Athena, another protectress of the Argonauts, contemplates ways of securing the divine fleece. The wise goddess Pallas Athena admits that she cannot think of a trick that will ensure success:

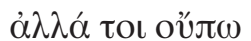

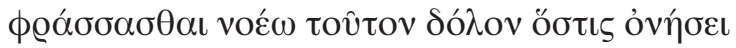

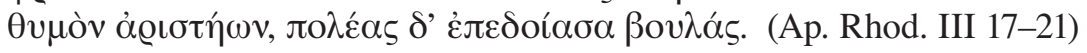

${ }^{10}$ WiLliams-Meadows 2001, 48. 
... but as yet,

though I've weighed up numerous plans to boost the heroes' spirits, I still don't feel I've hit upon the right one.

Hera therefore suggests visiting Aphrodite to win Medea's assistance for the Argonauts. Since Athena is inexperienced in matters of love, she follows Hera's advice. As such, Apollonius' Hera finds herself in the presence of the goddess of love in the role of a supplicant, like Homer's chief goddess a few centuries previously and Valerius' Juno generations later. In contrast to her Greek predecessor and her Roman successor, Apollonius' goddess speaks truth, and asks for what she desires without pretention (Ap. Rhod. III 56-75). The words of Valerius' Juno assuring the truth thus feel, for those familiar with Homer's and Apollonius' epics, especially juicy.

Let us now briefly come back to Apollonius' Chalciope, however. She would love to ask her sister for help for the Argonauts, but fear prevents her from doing so (Ap. Rhod. III 611-15). Medea, gradually falling in love with courageous captain, would also like to be of help. However, she is uncertain of what excuse she could make up (not to reveal her true feelings). Eventually, she decides to visit Chalciope (Ap. Rhod. III 641-644). She hopes that Chalciope herself asks her for help for her own sons and as such also for the Argonauts. After some difficulties, the two sisters indeed meet in Medea's bedroom both longing for the same result, that is, for Medea's support of the Argonauts (Ap. Rhod. III 661ff.). Medea pretends to care for Chalciope's sons and Chalciope appreciatively pronounces the words that Medea wishes to hear - asking her to support the Greek heroes. In this way, the unity of the princess of Colchis and the chief of the Argonauts is prepared.

In his poem, Valerius Flaccus does not actually engage Chalciope herself, but Juno in disguise as Chalciope: Chalciopen imitata sono formaque sororem (Val. Fl. VI 479). She comes armed with Venus' magic belt in order to dazzle Medea with Jason, for which reason she encourages Medea to take part in an unusual show, a fight of the courageous Greek heroes on the side of Aeëtes (Val. Fl. VI 477ff.). Medea and Chalciope take a seat on the rampart and in the course of the teichoskopia Juno lets the magic hidden in the belt take effect. The result of this moment is similar to the meeting of Apollonius' Chalciope with Medea. Inevitably, the princess of Colchis makes the decision to support the foreigners in their task (Val. Fl. VII 323-326), and Juno thus takes on the role of Apollonius' Chalciope.

In light of the foregoing, Valerius' Juno may thus appear to be a merely moody and subversive goddess who plays with the pretexts of her author, albeit flipping these wittily. This would be a simplistic view, however, since Juno can also be merciful to Valerius' literary predecessor and correct an oversight in his text. ${ }^{11}$ For instance, we meet such a character of the goddess on the way to Colchis, in the Symplegades episode. When Apollonius' heroes sail through the clashing rocks, they are helped by Athena, who holds one of the rocks with her left hand and moves the boat forward with Apollonius.

${ }^{11}$ See HershKowitz 1998, 48, who presented the following example of Valerius" "proofread" of 
her right hand (Ap. Rhod. II 537ff.). Although goddess Hera is not explicitly mentioned in the text here, later Zeus' wife attributes the success of Jason's voyage at Symplegades to herself (Ap. Rhod. IV 786-788). Valerius' Juno, perhaps in an attempt to make up for her colleague's inadvertence, really does intervene, coming down the sky towards the approaching clashing rocks and preventing one of them from crushing the sailing Argonauts (Val. Fl. IV 683-685); the other rock is then stopped by Minerva, and so Valerius' Argonauts reach the Black Sea with the same result as those of Apollonius, but with continuous divine support.

In a different place, Valerius' Juno socia sets off to help one of Valerius' characters rather than Jason himself. ${ }^{12}$ The seer Mopsus prophesies that one of the Argonauts, Hylus, is to die on his way to collect water with a jar, which indeed happens, albeit not in Valerius Flaccus' version, but in that of Apollonius Rhodius:

'heu quaenam aspicio?...।

... per quot discrimina rerum /

expedior! subita cur pulcher harundine crines /

velat Hylas? unde urna umeris niveosque per artus caeruleae vestes?'

(Val. Fl. I 211-220)

"Alas! what is this sight I see!... I find my way now through many a change of fortune! Ah! wherefore does fair Hylas of a sudden veil his locks with rushes? Whence the pitcher upon his shoulders that blue raiment upon his snowy limbs?"

In the Greek version of the Argonautica, the young man goes off to a well to collect water for his friend Heracles:

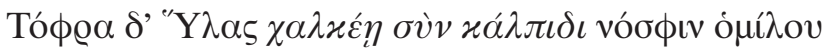

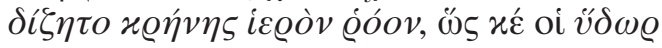

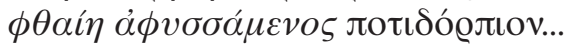

(Ap. Rhod. I 1207ff.)

Meantime Hylas with pitcher of bronze in hand had gone apart from the throng, seeking the sacred flow of a fountain, that he might be quick in drawing water for the evening meal...

There his beauty turns fatal to him as one of the nymphs falls in love with him at first sight and draws him down to her. Valerius' Hylas, in contrast, leaves the voyage in the chase of a deer (Val. Fl. III 549ff.). When wanting to refresh at a well after the unsuccessful hunt, he is pulled down by a nymph, but this time on Juno's impulse. The chief goddess once again wishes to follow her private pursuits, that is to force hated bastard Hercules out of the Argonautic group - hence the deer for the excited young hunter Hylas and the love lust of the lonely nymph. She expects Hylas' disappearance to bring

${ }^{12}$ See HershKowitz 1998, 152. 
a suitable chance for getting rid of his unhappy friend. Her subversive act saves the good name of the seer Mopsus, however. Although no jar can be seen in Hylas' hands at the moment of his drowning in the well, the prophecy is fulfilled. And, obviously, in antiquity all mortals are aware of the indirectness of signs that the Gods send to them. The outcome of the prophecy does come true.

In conclusion, as shown in this brief interpretation of Juno's character in the Argonautica of Valerius Flaccus, Juno is not only to be viewed as an assisting goddess - Juno socia - as suggested by Werner Schubert, but also as a product of Valerius' careful reading of epic poetry and of his permanent engagement in an intertextual dialogue with Homer and Apollonius Rhodius. Presenting his chief goddess, Valerius Flaccus thus continued in the way shown by his great master Virgil. ${ }^{13}$

Irena Radová

Department of Classical Studies

Masaryk University, Brno

Czech Republik

\section{BIBLIOGRAPHY}

BuCHHEIT, V. 1963: Vergil über die Sendung Roms. Heidelberg

EHLERS. W.-W. (ed.) 1980: C. Valeri Flacci Argonauticon libri octo. Stuttgart

FEENEY, D. C. 1984: The Reconciliation of Juno. Classical Quarterly 34, pp. 179-194.

FEEnEY, D. C. 1993: The Gods in Epic: Poets and Critics of the Classical Tradition. Oxford

FRÄNKEL, H. (ed.) 1961: Apollonii Rhodii Argonautica. Oxford

HERSHKOWITZ, D. 1998: Valerius Flaccus Argonautica: Abbreviated Voyages in Silver Latin Epic. New York

IANELL, G. (ed.) 19413: P. Vergili Maronis Aeneis. Leipzig

Mozley, J. H. (transl.) 1972: Valerius Flaccus, Argonauticon libri octo. Cambridge

Murray, A. T. (transl.) 1924: Homer, Ilias. Cambridge, MA-London

SCHUBERT, W. 1991: Socia Juno: zur Gestalt der Götterkönigin in Valerius Flaccus Argonautica. In Korn, M. - Tschiedel, H. J. (Hrsg.): Ratis omnia vincet. Untersuchungen zu den Argonautica des Valerius Flaccus. Hildesheim-ZürichNew York, pp. 121-137.

WeST, M. L. (ed.) 1998: Homeri Ilias. Stuttgart

Williams, J. - Meadows, A. 2001: Moneta and the Monuments: Coinage and Politics in Republican Rome. Journal of Roman Studies 91, pp. 27-49.

${ }^{13}$ See FeEney 1993, 157. 
